\title{
Effectiveness of Wholistic Education among SDA Secondary Schools in Arusha and Kilimanjaro Regions, Tanzania
}

\author{
Benson Mseli \\ ORCID: 0000-0002-6653-0659 \\ Directorate of Graduate Studies \\ University of Arusha, Tanzania \\ Dr. Onesto Ozias llomo \\ ORCID: 0000-0002-7226-4051 \\ School of Education \\ University of Arusha, Tanzania \\ *Corresponding Mail: oilomo@yahoo.com
}

\begin{abstract}
Copyright resides with the author(s) in terms of the Creative Commons Attribution CC BY-NC 4.0. The users may copy, distribute, transmit and adapt the work, but must recognize the author(s) and the East African Journal of Education and Social Sciences
\end{abstract}

\begin{abstract}
This study was conducted among SDA secondary schools in Arusha and Kilimanjaro regions to establish the effectiveness of wholistic Education. Out of five schools, three were randomly selected for participation. The three schools had a total of 120 Form Four students from whom 92 were selected to fill the questionnaire through simple random sampling. The analysis involved descriptive statistics, $t$ test and Pearson Correlation. The study concluded that wholistic education is effective in the schools under investigation. This is due to the fact that students, regardless of their religious affiliation, agreed with most of items that measured the variables in the questionnaire. Furthermore, there is significant positive relationship between the physical, the spiritual and mental aspects of the wholistic education. Therefore, there is need for leadership in schools under investigation to improve the quality of food provided to students since they were not satisfied with the quality of food provided. Since the physical, mental and spiritual aspects correlate with one another, there is need to ensure a balanced curricular and extra-curricular programs that accommodate the three aspects so that learners may receive quality and balanced education which prepares them physically, mentally and spiritually for better service in this world and in the world to come.
\end{abstract}

Keywords: Wholistic, Adventist, education, physical, mental, spiritual, teaching, learning.

How to cite: Mseli, B., and Ilomo, O. O. (2021). Effectiveness of Wholistic Education among SDA Secondary Schools in Arusha and Kilimanjaro Regions, Tanzania. East African Journal of Education and Social Sciences 2(4), 89-96. Doi: https://doi.org/10.46606/eajess2021v02i04.0131

\section{Introduction}

Seventh-day Adventist (SDA) Church integrates education in its beliefs and practice. The SDA Church uses education as one of the methods to fulfill its mission by acknowledging that development of mind and character is essential for God's redemptive plan (Knight, 2016). According to Fullerton (1985), the SDA church right after its inception believed that the provision of formal education can serve as an authentic tool for evangelism and socio-economic development in the community, the country and the world at large. Seventh-day Adventists believe humanity's ultimate purpose is to love and serve God and fellow men (White, 1903). Therefore, instruction and learning 
provided by Adventist institutions is to help the student achieve that objective.

Adventist learning institutions provide wholistic education to ensure harmonious growth and development of students to be responsible members of the society. According to Oti-Agyen (2014), immediately after the denomination was established in 1863, Seventh-day Adventists have promoted wholistic education as a means for learners to acquire knowledge within the Christian worldview. Beardsley-Hardy (2017) stated that "as of December 31, 2015, the Seventh-day Adventist Church worldwide operated 5,705 primary schools, 2,336 secondary schools and 53 training schools. These include hospital-based nursing programs, some non-degree ministerial training schools and 114 tertiary colleges and universities."

In Tanzania, Adventist education is offered in various schools. Both Northern and Southern Unions of the SDA Church in the country and their subsidiary Conferences and Field Missions have ownership of educational institutions. While General Conference of The Seventh-day Adventist Church (2020) has listed only 15 SDA owned Educational Institutions in Tanzania, there are more than 24 in the territory. Kilimanjaro Region has Chome, Suji and Parane Secondary Schools while Arusha Region has Tanzania Adventist Secondary School. These schools are accredited by the Adventist Accrediting Association.

Adventist Secondary Schools strive to offer wholistic education to enrolled students. Parents send children to Adventist schools because they need them to acquire true education which is the ultimate purpose as distinguished by a mere path to wealth and fame. The process of choosing a better school is informed by the educational objectives parents value for their children (Ibrahim, 2013). Most Christians are more focused on objectives related to personal achievement and social skills with higher priority on spiritual goals (Asadullah, 2012). Character and spiritual development are among the ultimate purposes of education which children should acquire (Powel, 1999).

Training young people for the mission of sharing the good news of salvation with others was and still is a major driving force in the development of the fastgrowing Adventist education. According to Knight (2016), true education offered by Adventist learning institutions has a broader meaning and perspective to facilitate human beings to regain and retain their original relationship with their creator. The education of this type gives more than academic knowledge. It brings about the development of the person in a wholistic approach which means a person needs to harmoniously develop the spiritual, physical, intellectual and social-emotional aspects (White, 1903). Therefore, the Adventist learning institutions are divine agencies to create good inhabitants in this world and for eternity. This study was guided by three research questions:

1. What is the students' perception of the effectiveness of the physical, the mental and the spiritual aspects of the Wholistic Education among Seventh Day Adventist Secondary Schools in Arusha and Kilimanjaro regions?

2. Is there significant difference in perception of the Wholistic education by students categorized according to SDA membership status among SDA Secondary Schools in Arusha and Kilimanjaro regions?

3. Is there significant relationship between various aspects of Wholistic education among the SDA Secondary Schools in Arusha and Kilimanjaro regions?

\section{Literature Review}

This section presents the theoretical and empirical literature regarding the Adventist education system. Adventist education maintains that true education means more than the perusal of a certain course of study. It means more than a preparation for the life that now is. It has to do with the whole being and with the whole period of existence. True education is wholistic in nature involving a harmonious development of the physical, the mental and the spiritual aspects. True education further prepares the learner for the joy of service in this world and for the higher joy of wider service in the world to come (White, 1903).

Seventh-day Adventist schools constitute a system that aims to bring children closer to their creator. The primary aim of SDA education is to provide opportunity for students to accept Christ as their Savior, allowing the Holy Spirit to transform their lives in order to fulfill the commission of preaching the gospel to the entire world (Arego, Makewa and Role, 2014). As it was illustrated by White (1903), the work of education and the work of redemption are one. Introducing students to Jesus as savior 
should therefore be the ultimate goal in every Adventist classroom.

Adventist education system traces its background to Eden. The Garden of Eden was a representation of what God desired the whole earth to become. It was a classroom where the instructor who was God himself illustrated a principle model for the human history. In the Garden of Eden, there was a face to face communication between God and his people. God committed Adam and Eve to take care of the Garden of Eden by dressing and keeping it. This demonstrates that true education must include hands-on activities (White, 1903). In the same way, Christian teachers must communicate God's message to the learners in the teaching and learning process and include hand-on activities.

\section{Adventist Philosophy of Education}

Adventist education involves the harmonious development of the physical, the mental and the spiritual aspects (White, 1903). While God is the source of true education, true education prepares the learner for the joy of service in this world and for the higher joy of wider service in the world to come. It promotes development of the body, the mind and the soul. The Seventh-day Adventist Church was founded on firm biblical principles, an unwavering belief in the Second Coming of Jesus and the all-encompassing redeeming grace of Jesus. These doctrines directed the formation of the Adventist educational system as early church members built schools that would academically educate and spiritually nurture the children. The desire for quality education met with the conviction to share Adventist beliefs and in that intersection, Adventist education was born (Knight, 2010).

Effectiveness of an Adventist learning institutions depends highly on how they deliver education in accordance with the objectives and the underlying philosophy. In the context of wholistic education, the school must be able to deliver and develop students in physical, spiritual and mental aspects of human life. It is also added by Fullerton (1985) that Adventist education should prepare people for useful and joy-filled lives, fostering friendship with God, whole person development, Bible-based values and selfless service. Adventist philosophy of education is appraised by Ngussa (2020) who conducted a study across Adventist higher learning institutions in East-Central African region and established a positive correlation between wholistic aspects and students' attitude towards learning. The aspects of Adventist education are explained below:

\section{The Physical Aspect}

Adventist education helps students to reflect God's image while developing proficiency in the area of physical education which includes cognitive abilities, movement competency, lifetime fitness and healthful living. Koeppe (2014) stated that physical education aims to develop students' competence and confidence to take part in a range of physical activities that become a central part of their lives, both in and out of school. According to White (1898), Jesus was the best in every line including the physical aspect. He was not willing to be defective, even in the handling of tools. He was perfect as a workman as He was perfect in character. Much as education systems activates the mental abilities of the learners, the Adventist Education Physical Education Standards (2016) proposes that physical education which entails motor skills, performance application and physical fitness should be part and parcel of our education systems.

\section{Spiritual Aspect}

White (1903) states that Adventist education should prepare the learner for joy of service in this world and for the higher joy of wider service in the world to come. This clearly demonstrates that any Adventist school must incorporate the spiritual aspect in education. Mutero (2017) supplements that Adventist schools should be cities of refuge for young people living in the broken world full of moral decays such as drug abuse, alcoholism and immorality. Arego et al (2014) added that students completing secondary education at Adventist schools should have had opportunities to commit their lives to God and manifest a maturing faith in $\mathrm{Him}$ as reflected by personal devotion as well as service and witness to others in fulfillment of the churches' mission. Adventist secondary schools are needed to be instruments for spiritual development because children spend most of their time in schools more than in churches.

\section{Mental Aspect}

The mental aspect of education is advocated by White (1974) who argues that the relation that exists between the mind and the body is very intimate. When one is affected, the other sympathizes. She argues that the condition of the mind affects the health to a far greater degree than one many realize. The mental aspect of education involves emotional well-being of a person. 
According to Scott (2018), while students in secondary schools encounter many significant biological, psychological and environmental changes, the mental aspect of education enables learning and supports processes that are used by a human being to learn and acquire expected competences.

\section{Research Methodology \\ Research Design}

The study used the descriptive-correlational design to describe the effectiveness of Adventist Education among SDA Secondary Schools in Arusha and Kilimanjaro Regions and to determine the relationship between variables. The first research question was analyzed through descriptive statistics in terms of mean scores and standard deviations. The second research question was analyzed through t-test while the third involved Pearson Correlations. The study employed a questionnaire as data collection instrument. The questions had closed ended items in the format of five point Likert scale.

\section{Population and Sampling}

The study took place in two administrative regions of Arusha and Kilimanjaro. Arusha region, part of the Tanzania Rift Valley Field (TRVF) of the SDA Church has one secondary school namely Tanzania Adventist Secondary School (TASS). On the other hand, Kilimanjaro Region is a part of the North East Tanzania Conference (NETCO) with three secondary schools namely Suji Secondary School, Parane Secondary school and Chome Secondary School (General Conference, 2020). Simple random sampling procedure was used where all individuals in the population had equal chances to be selected. As a result, TASS, Suji and Chome Secondary Schools were selected to participate in the study. A sample of 92 students was randomly picked from the population of 120 Form Four students to fill the questionnaire.

\section{Ethical Consideration}

To ensure ethics in this study, no bias was allowed. Each respondent was asked to fill the consent form before proceeding with data collection. Permission was sought from the SDA church authority before visiting the schools for data collection.

\section{Results and Discussion}

Questionnaire items were rated by respondents based on five points in the questionnaire whereby 1 stood for Strongly Disagree, 2 Stood for Disagree, 3 stood for Neutral, 4 stood for Agree and 5 stood for Strongly Agree. The scale of mean score interpretation was as appears in table 1.

\begin{tabular}{lll}
\multicolumn{2}{l}{ Table1: Scale of Mean Score Interpretation } \\
\hline Mean & Rating & Interpretation \\
\hline $1.00-1.49$ & Very Low & Strongly Disagree \\
$1.50-2.49$ & Low & Disagree \\
$2.50-3.49$ & Undecided & Neutral \\
$3.50-4.49$ & High & Agree \\
$4.50-5.0$ & Very High & Strongly Agree \\
\hline
\end{tabular}

Research Question 1: What is the students' perception of the effectiveness of the physical, the mental and the spiritual aspects of the Wholistic Education among the SDA Secondary Schools in Arusha and Kilimanjaro regions?

There are three aspects of the wholistic education as described by the writings of Ellen G. White which underpinned this study. These are the physical, the mental and the spiritual.

\section{Physical Aspect}

As seen in table 2, there were seven items in the questionnaire which measured the physical aspect of the wholistic education in schools under investigation.

Table 2: Perception of Respondents on the Physical Aspect

\begin{tabular}{lllll}
\hline SN & \multicolumn{1}{c}{ Item in the Questionnaire } & \multicolumn{1}{c}{ Mean } & Std. Deviation & Interpretation \\
\hline 1 & We do Manual Works which Improve Physical Well Being & 3.93 & .970 & Agree \\
2 & Physical Education is effective & 3.67 & 1.140 & Agree \\
3 & The school insists Compulsory Physical Exercises & 3.61 & 1.317 & Agree \\
4 & Physical Exercise is Satisfactory & 3.49 & 1.153 & Agree \\
5 & Physical Exercise Facilities are Favorable and Conducive & 2.78 & 1.203 & Neutral \\
6 & Health Service is satisfactory & 2.54 & 1.171 & Neutral \\
7 & The quality of food provided is good & 2.08 & 1.251 & Disagree \\
\hline
\end{tabular}

The first four items were rated between 3.50 and 4.49 which means students agreed with such items. Particularly, they agreed that they do manual work which improves their physical wellbeing (mean=3.93), that the physical education is effective (mean=3.67), that the schools insists on compulsory physical education (mean=3.61) and that the physical exercises are satisfactory (mean=3.49). It is 
worth noting that students agreed that these ingredients of the physical aspect take place in the schools under investigation. Koeppe (2014) indicated that the physical aspect of education develops students' competence and confidence. In addition, White (1898) argued that Jesus himself was the best in every line including the physical aspect. He was not willing to be defective, even in the handling of tools. He was perfect as a workman, as He was perfect in character.

Two aspects, however, were rated 2.54 and 2.78 respectively, which means students were undecided whether the physical exercise facilities are available and whether the health services are satisfactory. Table 2 further indicates that students disagreed with the statements that the quality of food provided in schools is good (mean=2.08). This suggests that the food provided in the schools under investigation is not appreciated by the students and therefore, a need for schools to improve the type of food provided.

\section{Spiritual Aspect}

As seen in table 3, there were seven items in the questionnaire which measured the spiritual aspect of the wholistic education in schools under investigation. The first item in table three was rated very high by the mean score of 4.50 meaning respondents strongly agreed that the schools bring students closer to God. This is actually the essence of the Adventist education, introducing learners to God and thus, preparing them for eternity.

Table 3: Perception of Respondents on the Spiritual Aspect

\begin{tabular}{lllll}
\hline SN & Item in the Questionnaire & Mean & Std. Deviation & Interpretation \\
\hline 1 & Presence in Schools brings me closer to God & 4.50 & .671 & Strongly Agree \\
2 & The daily Devotion session is helpful in spiritual Development & 4.42 & .802 & Agree \\
3 & Spiritual programs are excellent & 4.16 & .905 & Agree \\
4 & Understanding Divine issues have Increased & 4.15 & 1.037 & Agree \\
5 & The school prepares good Evangelists & 4.13 & .963 & Agree \\
6 & Teachers Insist Spiritual development during Learning & 3.96 & .982 & Agree \\
7 & Chaplain Support Spiritual development & 3.68 & 1.334 & Agree \\
\hline
\end{tabular}

Table 4: Perception of Respondents on the Mental Aspect

\begin{tabular}{llccc}
\hline SN & \multicolumn{1}{c}{ Item in the Questionnaire } & Mean & Std. Deviation & Interpretation \\
\hline 1 & Administration prohibits Dirt talks & 4.30 & .935 & Agree \\
2 & I receive counseling when I need it & 3.77 & 1.039 & Agree \\
3 & Teachers Capacitate in Problem Solving Skills & 3.64 & 1.023 & Agree \\
\hline
\end{tabular}

Furthermore, the rest of the items under this aspect were rated high as students agreed with such statements in the questionnaire. Particularly, they agreed that daily devotion sessions are helpful for spiritual development (mean=4.42), spiritual programs are excellent (mean=4.16) and they have increased the understanding of divine issues with a mean score of 4.15. In addition, students agreed that the schools prepare evangelists by scoring 4.13 , that teachers insist on the spiritual development of the learners during the teaching and learning process (mean=3.96) and that the school chaplains support the spiritual development of the learners (mean=3.68). Similarly, Gane (2013) in his study on the Adventist School System and Values Transmission established that a big portion of students agreed that teachers showed them how to relate to God and transmitted Christian values. Beardsley-Hardy (2010) indicated that majority of children attending Adventist schools end up deciding to become baptized member of the Adventist Church and to support the church in various ways.

\section{Mental Aspect}

As seen in table 4, there were three items in the questionnaire which measured the mental aspect of the wholistic education in schools under investigation. The first three items were agreed upon by the respondents. Particularly, respondents agreed that the school administration prohibits dirty talks by scoring 4.30 mean.

They further agreed that they received counseling when they need it (mean=3.77) and that teachers concentrated on problem solving skills (mean=3.64) which enhanced the mental aspect. These findings are worth noting since according to White (1974), the relation that exists between the mind and the body is very intimate. When one is affected, the other sympathizes. The positive results regarding 
the mental aspect are likely to affect the physical aspect positively which will increase chances for students' wellbeing and therefore effective academic performance.

Research Question 2: Is there a significant difference in the perception of the wholistic education by respondents categorized according to SDA membership status?

This research question sought to determine whether the perception of the learners regarding the wholistic education differs when learners are categorized according to their SDA membership status.

The research question called for testing of the null hypothesis which states: there is no significant difference in the perception of the wholistic education by respondents categorized according to SDA membership status.

The researchers planned to determine whether the SDA learners have the same or different perception regarding the wholistic aspect when compared with the non-SDA members as described in table 5 and 6.

Table 5: Group Statistics for Perceptions by SDA Membership Status

\begin{tabular}{lccccc}
\hline & Do you have SDA membership? & N & Mean & Std. Deviation & Std. Error Mean \\
\hline WHOLISTIC & Yes & 58 & 3.7356 & .51565 & .06771 \\
& No & 34 & 3.5637 & .63874 & .10954 \\
\hline
\end{tabular}

Table 6: Independent Samples Test for Perceptions by SDA Membership Status

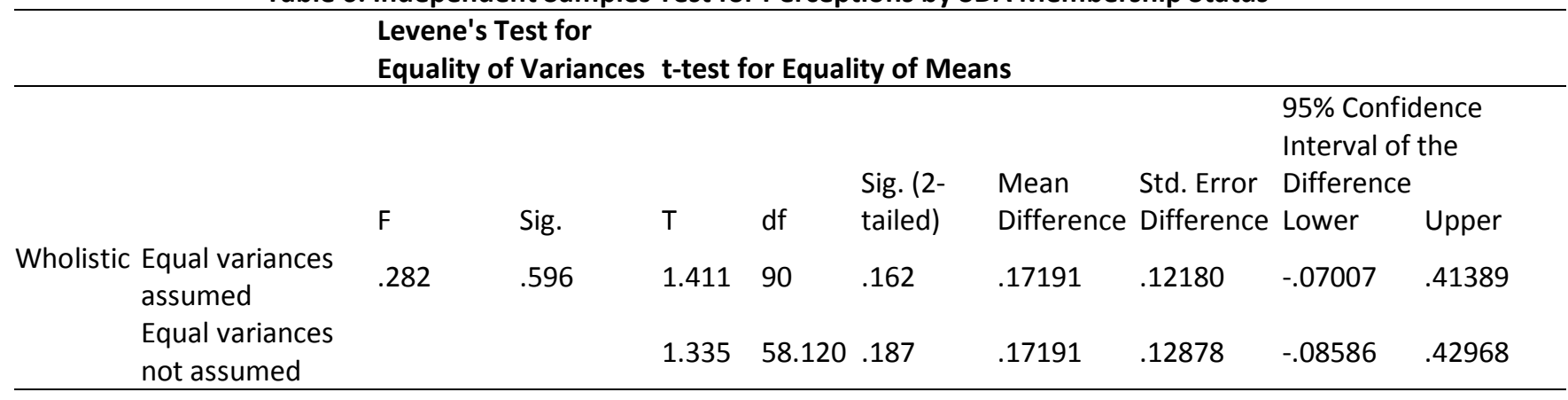

Table 5, presents 3.7356 as the mean score for Adventist students while the mean score for nonAdventists is 3.55637 .

Although the mean score for Adventists is slightly higher than for the non-Adventists, both mean scores are within the agreement level 3.50-4.49 meaning, students, whether they are Adventists or not, agreed that the schools under investigation provides the wholistic education. Furthermore, through the independent sample t-test in table 6, the $p$ value of .187 is greater than the critical value, meaning the mean score difference happens by chance and the null hypothesis is accepted. Therefore, there is no significant difference in the perception of the wholistic education by respondents categorized according to SDA membership status.

Research Question 3: Is there a significant relationship between various aspects of wholistic education in Adventist secondary schools?
Finally, the researchers sought to establish whether the three aspects of the wholistic education interrelate. This objective was met through the testing of a null hypothesis which stated: there is no significant relationship between various aspects of wholistic education in Adventist secondary schools. The hypothesis was tested through the Pearson Correlations as reflected in table seven.

Table 7 (p. 95) indicates that the correlation of the wholistic aspects is significant at the 0.01 level (2tailed). Therefore, the null hypothesis is rejected. Particularly, the table shows that the physical aspects positively relates with the spiritual aspect (Sig=.000, $r=.433$ ) and with the mental aspect (Sig=.000, $r=.479$ ). Since this relationship is positive, the physical aspect enhances the spirituality and the mental aspect of the learners. This is true because when students are busy with physical activities, they will have no time for useless issues, but will study hard and devote some of their time for spiritual activities. 
Secondly, the table shows that the spiritual aspect positively correlates with the mental aspect (Sig=.000, r=.636). This implies that when the mental is fed with the right food, students receive spiritual benefits, as their mind will be avoided to deal with evil thoughts.

Table 7: Interrelatedness of the Wholistic Aspects

\begin{tabular}{llccc}
\hline & & PHYSICAL & SPIRITUAL & MENTAL \\
\hline PHYSICAL & Pearson Correlation & 1 & $.433^{* *}$ & $.479^{* *}$ \\
& Sig. (2-tailed) & & .000 & .000 \\
\multirow{3}{*}{ SPIRITUAL } & $\mathrm{N}$ & 92 & 92 & 92 \\
& Pearson Correlation & $.433^{* *}$ & 1 & $.636^{* *}$ \\
& Sig. (2-tailed) & .000 & & .000 \\
\multirow{3}{*}{ MENTAL } & $\mathrm{N}$ & 92 & 92 & 92 \\
& Pearson Correlation & $.479^{* *}$ & $.636^{* *}$ & 1 \\
& Sig. (2-tailed) & .000 & .000 & \\
& $\mathrm{~N}$ & 92 & 92 & 92 \\
\hline
\end{tabular}

**. Correlation is significant at the 0.01 level (2-tailed).

This finding matches with that of Ngussa (2020) who investigated on the influence of wholistic aspects on students' attitude toward learning among the Adventist universities in East-central Africa and established that the spiritual aspect positively correlated with the mental aspect.

\section{Conclusions and Recommendations}

\section{Conclusion}

The study concludes that wholistic education is effective in the Adventist secondary schools under investigation. This is due to the fact that students, regardless of their religious affiliation, agreed with most of items that measured the variables in the questionnaire. Furthermore, there is significant positive relationship between the physical, the spiritual and mental aspects of wholistic education.

\section{Recommendations}

There is need for leadership in secondary schools under investigation to improve the quality of food provided to students since students were not satisfied with the quality of food provided, which is a key aspect for the physical aspect of wholistic education. Secondly, since the physical, mental and spiritual aspects correlate to one another, there is need to ensure a balanced curricular and extracurricular programs that accommodate the three aspects so that learners may receive quality and balanced education which prepares them physically, mentally and spiritually for better service in this world and in the world to come.

\section{References}

Adventist Education Physical Education Standards (2016). Accessed on http://pe.adventisteduc ation.org/standards.html on 12th April, 2021.
Arego, S., Makewa, L. \& Role, E. (2014). Factor Influences in the Implementation of Adventist Wholistic Education in Mara Conference, Tanzania. International Journal of Humanities and Social Science. 4(1), 4648.

Asadullah, N., Chakrabarti, R., \& Chaudhury, N (2012). What Determines Religious School Choice? Theory and Evidence from Rural Bangladesh. IZA DP No. 6883.

Beardsley-Hardy, L. \& Taylor, J. W. (2010). The Role of Seventh-day Adventist Education in Youth Retention. Journal of Adventist Education. 79(3), 39-44.

Beardsley-Hardy, L.M (2017). State of Adventist Education Report. Journal of Adventist Education 79:3 Available at https://jae.adventist.org/en/2017.3.3

Fullerton, V. (1985). The Basics of Adventist Education, What Are They? How Should They Be Taught? Journal of Adventist Education. 4(47), 8-12.

Gane, B (2013). The Adventist School System and Values Transmission. Educational Administration. Accessed on 28th August, 2021 on https://research.avo ndale.e du.a $\mathrm{u} / \mathrm{cgi} / \mathrm{v}$ iewc ontent.cgi?article=1 213\&conte $\mathrm{xt}=\mathrm{teach}$

General Conference of The Seventh-day Adventist Church. (2020). Educational Institutions in Tanzania. Available on http://www.adventi stdirectory.org/Searc hResults.asp x?Ctr yCode=TZ\&EntityType $=E$ Accessed on 22 July, 2020. 
Ibrahim, M. S. (2013). Accommodating Parental Participation in Managing School. Journal of Education and Practice. 4(12), 29-32.

Knight, G. R. (2010). Implications of Philosophy for Adventist Education; Redemptive Education. Journal of Adventist Education. 73(1), 47-56.

Knight, G. R. (2016). Education for What? - Thoughts on the Purpose and Identity of Adventist Education. Journal of Adventist Education. 79(1), 6-12.

Knight, G. R. (2006). Philosophy and Education: An Introduction in Christian Perspective, 4th ed. Berrien Springs, Michigan. Andrews University Press.

Knight, G. R. (2010). Myths in Adventism: An Interpretive Study of Ellen White, Education, and Related Issues. Hagerstown, Review and Herald Publishing Association.

Koeppe, K. (2014). Attitudes and Beliefs of Seventhday Adventists Concerning Psychology, Counseling, and Mental Health Issues Psychology, Counseling, and Mental Health Issues. Digital Commons, Andrews University.

Mutero, A. (2017). 7 Reasons Why We Still Need Adventist Education. Accessed on $22^{\text {nd }}$ July, 2020 on https://adventisteducators.org/ 2017/ 04/7-reasons-why-we-still-needadventist-education/
Ngussa, B. M. (2020). The Influence of Holistic Aspects on Students' Attitude towards Learning; A Case Study of Advenstist Universities in East-Central Africa. Journal of Applied Social Sciences, Human Development, and Technology. 1(1), 16-24.

Oti-Agyen, P. \& Sarfo, F. K. (2014). Early Beginnings of the Educational Activities of the Seventh day Adventist (SDA) Church in Ashanti at Agona Township, Ghana, 1914 - 1932: Prospects and Challenges. Journal of Education and Practice. 5(26), 35-43.

Powell, N. \& Wood, T. (1999). Partnerships: Connecting Parent Involvement and Student Achievement. Journal of Adventist Education. 62(1), 17-19.

Scott, H. (2018). The Need for Mental Health Counselors in Adventist Schools. Accessed on $22^{\text {nd }}$ July, 2020 on https://spectru mmagazin e.org/views/2018/need-mentalhealth-counselors-adventist-schools

White, E. G (1898). The Desire of Ages. Mountain View, California. Pacific Press Publishing Association.

White, E. G (1903). Education. Mountain View, California. Pacific Press Publishing Association.

White, E. G. (1974). Ministry of Healing. Oshawa, Canada: Pacific Press. 